\title{
Lezama Lima: El Logos de la Imaginación
}

\author{
" "Buscando la increada forma del logos \\ de la imaginación'".
}

En uno de sus ensayos, Lezama Lima aborda el tema de la oposición entre letra y espiritu. El escriba moderno, dice, acogiéndose a la frase de las Escrituras: la letra mata, ha querido resucitar esa oposición como obstáculo para toda empresa creadora. Pero esa oposición, observa Lezama, no es sólo una inconsecuencia ética o un signo de la crisis germinativa de nuestro tiempo; se funda, sobre todo, en un malentendido. La letra mata al espíritu cuando ya éste se ha extinguido. Cuando faltare la visión, el pueblo será disipado-recuerda Lezama recordando el "Libro de los Proverbios". Y, con una idea que sin duda es central en toda su obra, concluia ese ensayo afirmando:

Vivimos ya un momento en que la cultura es también una segunda naturaleza, tan naturans como la primera; el conocimiento es tan operante como un dato primario. El extremo refinamiento del verbo poético se vuelve tan primigenio como los conjuros tribales. ${ }^{1}$

Esta idea es central no sólo por lo que ella en sí misma encierra: vale decir, la visión afirmativa que Lezama tiene de la literatura. Lo es, sobre todo, por la desmesura de esa visión. Se trata, en efecto, de algo más que del mero derecho de existencia de la literatura. Lo que quiere formular Lezama, en verdad, es un sistema poético del mundo, y aun de la historia.

La literatura es una segunda naturaleza no porque ella represente o presente lo real--lo cual sería, para kezama, recaer en un realismo ya insano. Si ella es representación de algo lo es de sus propios poderes; su verdadero carácter es lo incondicionado: un germinar que es una continua opción (o viceversa, que es igual para Lezama) y lo bipertélico: siempre va más allá de sus propios fines. Como Pascal, Lezama cree que la naturaleza se ha perdido y que todo puede reemplazarla. "Hay inclusive--dice--como la obligación de devolver la naturaleza perdida. De fabricar naturaleza, no de recibirla como algo dado"'. La literatura es más bien, pues, sobrenaturaleza: la imagen penetra en la naturaleza y la sustituye; así, frente ál determinismo de lo real el hombre responde con el total arbitrio de la imagen. En

1 Tratados de la Habana, 1958. 
efecto, ¿qué es la obra de Lezama. si no uno delos más fabulosos intentos por encarnar esa sustitución, por ser ella misma naturaleza? No sólo por sus vastos desenvolvimientos, o por el carácter absoluto que adquieren sus imágenes, o por ese orden a la vez fijo y vertiginoso que subyace en toda ella--lo que, a su vez, se traduce en el movimiento de la dispersión y el reencuentro: un signo que oscuramente se pone en marcha, luego de una travesía imprevisible es rescatado e iluminado por otro signo; o, como diría Lezama, la obra sometida a la "ley de los torbellinos". La impresión de ser naturaleza la suscita también ese carácter suyo de cuerpo o materia que se va expandiendo--y concentrando, endureciéndose--con sucesivas acumulaciones y sedimentaciones. De ahí el poder que Lezama reconoce en el poema: el de crear " un cuerpo, una sustancia resistente enclavada entre una metáfora, que avanza creando infinitas conexiones, y una imagen final que asegura la pervivencia de esa sustancia, de esa poiesis". En un poema, que de manera significativa se titula La sustancia adberente, Lezama nos da esta visión:

Si dejásemos nuestros brazos por un bienio dentro del mar se apuntalaría la dureza de la piel hasta frisar con el más grande y noble de los animales y con el monstruo que acude a sopa y a pan... Al pasar los años, el brazo sumergido no se convierte en árbol marino; por el contrario devuelve una estatua mayor, de improbable cuerpo tocable, cuerpo semejante para ese brazo sumergido. Lentísimo como de la vida al sueño; como del sueño a la vida, blanquísimo.

Como ese brazo sumergido en el mar, el lenguaje de Lezama parece germinar recubriéndose con su propia sustancia y sólo se somete al dinamismo de esa misma germinación. Es posible que la metáfora de Lezama evoque la que empleaba Stendhal para ilustrar su teoría del amor como "cristalización": la ramita sumergida en las minas de sal de Salzburgo, que se iba cubriendo de cristales. Pero no sólo se diferencian por su punto de partida sino también por su teleología. En efecto, Stendhal parte de un hecho obśervable para ilustrar un proceso psicológico o espiritual; Lezama parte de un hecho sólo posible imaginariamente y que no puede servir de ilustración sino de sí mismo. Así, el brazo sumergido no cristaliza sino en un "cuerpo semejante": no se convierte en "árbol marino" sino en estatua de "improbable cuerpo tocable". Es significativo, por cierto, que esta última fórmula resulte reversible. Si dijéramos: "probable cuerpo intocable", el cambio de estructura no se resuelve en una transferencia de sentido: aun invertida, la fórmula se retleja y sólo puede reflejarse a sí misma.

Desde la perspectiva que antes hemos resumido, es obvio que la obra erige su total autonomía frente a lo real. Pero si esa autonomía es la ruptura de la causalidad realista, el hecho es que por efecto de lo que Lezama llama la vivencia oblicua 2 la obra penetra en "la causalidad de las excepciones": entonces su irrealidad comienza a cobrar existencia, no porque se mimetice a lo real, sino por las transfiguraciones inesperadas de su irrealidad misma. La obra, así, no nos regresa al mundo, nos lo inventa: " "todo está dispuesto--anota Lezama--para un nacimiento, no para una repetición"'. Pero inventar el mundo consiste en

2 “"Como si un hombre, sin saberlo desde luego, al darle la vuelta al conmutador de su cuarto inaugurase una cascada en el Ontario', Orbita de Lezama Lima, 1966. Ver también su ensayo "La Dignidad de la Poesía", en Tratados, op. cit. 
devolverle su originalidad-una originalidad, por cierto, muy singular: su tiempo es simultáneamente el pasado y el futuro. La misión de la literatura--de la poesía, dice Lezama--es "empatar o zurcir el espacio de la caída". Cerrar las fisuras de ese espacio es ya saltar hacia la imagen venidera y última: lo que Lezama define como "el éxtasis en lo homogéneo". ¿No es, en cierto modo, lo que proponía Baudelaire: el progreso reside en "la diminution des traces du péché originel"?

"Mejor que sustituir, restituir", dirá, por ello, Lezama en un poema. Restituir, claro, no tiene una connotación realista; en el contexto de la obra de Lezama, es evidente que alude a la naturaleza perdida. ¿Cómo, entonces, restituir lo perdido sin apelar a las sustituciones y, en consecuencia, cómo prácticar estas sustituciones sin aventurarse en lo imaginario? Restituimos algo, por tanto, creándolo-- "invencionándolo", como diria Lezama. Sólo que esa invención se ve regida por una ley que el propio Lezama formula: encontrar las coordenadas entre lo imaginario y lo necesario ("entre su absurdo y su gravitación", dice él), entre el súbito de la imagen y la extensión que ella despliega. Esas coordenadas se inscriben, a su vez, en un movimiento más amplio, con el cual Lezama define el acto poético: toda realidad poética (o teocéntrica) suscita una reacción de irrealidad que, por su parte, quiere encarnar en aquella realidad. La imagen para Lezama, sabemos, nunca es un doble, ni siquiera una sustitución. La imagen es "la realidad del mundo invisible", la resistencia final en que el poema toma cuerpo. Pero, no olvidemos, un cuerpo--como señala Lezama, con palabras de Dante--"adquirido por la sombra de los fantasmas". También en uno de sus poemas, él dice: "Respiro la niebla/ de deshojar fantasmas". Un cuerpo, pues, igualmente irreal, un cuerpo que "se sabe imagen", pero que se intuye también necesario, gravitante, susceptible de engendrar por sí mismo nuevas gravitaciones.

Así, lo que intenta en el fondo Lezama, creo, es ejercer la autonomía verbal dentro de un verdadero sistema poético del mundo. Un sistema que abarcaría las dos fórmulas propuestas por Novalis: la poesía como lo real absoluto y la filosofia como la operación absoluta. Sólo tal sistema podría reemplazar a la religión (¿no se ha perdido la religión como se ha perdido la naturaleza?) en la medida, explica Lezama, en que sería "la más segura marcha hacia la religiosidad de un cuerpo que se restituye y se abandona a su misterio".

\section{EL ESPEJO DE SU ENIGMA}

Restituirse y abandonarse a su misterio: esta frase parece sugerir un mismo movimiento de dos fases: lo que se revela y a un tiempo se vela. También, como ninguna otra de Lezama, esa frase evoca el carácter mismo de su obra, especialmente de su obra poética. Nos conduce, por supuesto, a un punto crucial de ella: su hermetismo. Es sabido que Lezama no sólo no niega sino que además reivindica ese hermetismo. En sus conversaciones ha dicho: "mi trabajo oscuro es mi poesia", "mi obra puede considerarse una penetración en mi oscuro"' Tampoco lo problematiza: el sexo como la poesía, para uno de los personajes de Paradiso, es materia concluyente, no problemática. No está demás decirlo: el hermetismo de Lezama es un modo de ser, está ligado a un discurso que busca oscuramente su ser. Quizá por ello nunca accede a hacer depender ese hermetismo de una 
clave que en sí misma ya sea clara--lo que puede resultar una comodidad, pero no lo es. Es cierto que Lezama concibe su sistema poético regido por la razón. Frente a los términos de la escolástica: ente de razón fundado en lo real, que en poesía daría: ente de razón fundado en lo imaginario, él prefiere otra relación: ente de razón fundado en lo irreal. Sin ser menos lúcida, su opción evidentemente es inconmensurable: aventura no sólo en lo imaginario como imaginable, sino también en lo aún no creado; la luz que ya no sólo trabaja en sus propios dominios, sino igualmente, y sobre todo, en la sombra. Hay quienes se reconocen en "la suprema esencia y la suprema forma"'--dice Lezama en un poema--, pero a él sólo se le hace "visible la caída y la originalidad por"la sombra y la caída". La suya es, pues, una razón oracular: propone un mundo, posible o imposible, no' dispone de uno ya dado.

Por lo general, pensamos, el hermetismo no es más que un juego sutil o ingenioso de sustituciones: como Góngora, no nombrar la mesa o el halcón sino decir " "el cuadrado pino" o "raudo torbellino de Noruega" ; o como Valéry, no nombrar el mar y los veleros sino decir: "Ce toit tranquille, oú marchent des colombes". Parece, en efecto, que todo radicara en eso y por tanto, ya descifrado el código, aun en sus implicaciones más encubiertas o eruditas, el juego resulta ser un previsible sistema de equivalencias. El aparente triunfo de la hermenéutica nos aleja, sin embargo, de lo esencial: de la magia del juego, de su ironía también, que no es simplemente ingenio. Nos olvidamos que esas sustituciones son verdaderas metamorfosis: su valor no está tanto en la (trans)figuración de un objeto como en las relaciones sucesivas que suscitan; aparte de que, muchas veces, esas sustituciones, como ha explicado Valéry, no aluden sino a estados más complejos no nombrados antes y hasta innombrables. Son, en verdad, como diría Lezama, naturaleza creada que nos pone en presencia de una naturaleza original: nos hacen ver, en efecto, con los ojos de una imaginación primigenia. Por otra parte, son también una continua derrota del puro sentido y el abandono a los poderes encantatorios del lenguaje: el ritmo puede contar más que la significación; el orden sintáctico, sugerir valores puramente espaciales. ¿Cómo pretender, entonces, trasponer lo hermético a un sistema de meras equivalencias lógicas o realistas, sin simplificarlo rebajándolo y aun distorsionándolo?

“E1 juglar hermético, que sigue las usanzas de Delfos, ni dice, ni oculta, sino hace señales", afirma Lezama en su ensayo sobre Góngora. "La flota del vino desea que las aguas no la interpreten", dice también en un poema. Es obvio que su hermetismo se inscribe en este contexto: su poesía emite señales, pero señales que son símbolos que encarnan en signos, no al revés. Sustituciones que son metamorfosis, señales que adquieren la autonomía de la progresión infinita: es este poder del signo lo que Lezama subraya. Constantemente en su obra tiende a acentuar lo imaginario como tal, incluso a mostrar al lector el proceso a través del cual una imagen se va gestando. Así, en un poema, Lezama habla del tiburón y lo precisa con una metáfora que, si bien es más alquimista que puramente sensorial, nos da una visualidad: "ancha plata--dice--en el ancho plomo acelerado" '; luego de otra metamorfosis en que el tiburón (ahora es una "lenta columna de impulsado plomo horizontal" ') surge de las aguas (cumpliendo "su dictado de obturar las deformidades y las noblezas, la mansa plata y el hierro corrugado"), deriva en esta visión de doble fondo:

El humo de la evaporación secretada ha manoteado en la cacerola rocosa, que así 
aflije a la piedra un toque muy breve del hilo que se ha desprendido de la Energía .

Con la metáfora "'el humo de la evaporación secretada", se está aludiendo al tiburón desde dos perspectivas simultáneas: el acto en que surge del mar y a la vez en que surge de la imaginación misma, puesto que para Lezama toda imagen es una "evaporación'”. Esa simultaneidad de planos nos conduce, pues, a ver al tiburón surgiendo sobre todo de la mirada que lo mira. Así, nos recuerda Lezama, más que una realidad o una irrealidad, el tiburón es simplemente un signo que, a su vez, emite otros signos: el bumo de su evaporacion hace que las rocas, como en una culinaria alquímica, se transfiguren en cacerola rocosa. El poema todo, en verdad, es un gran hervidero cósmico. $\mathrm{Y}$, contrariamente a su título Censuras fabulosas, explicita al final la simbología de los elementos que lo constituyen: "La roca--se nos dice--es el Padre, la luz es el Hijo. La brisa es el Espíritu Santo'”. En contra de todas las reglas de una poesía hermética, el juglar Lezama descifra su código: lo hace no sólo con cierto dejo irónico en el sentido de hacer impracticable la hermenéutica, sino también para mostrar (ironía final) que toda analogía es más realde lo que suponemos. En otras palabras, la analogía no se funda tanto en un símil como en una metonimia: la relación de la parte (lo natural) con el todo (lo sobrenatural) puede derivar en la sustitución de éste por aquélla. Vale decir, la naturaleza que nos presenta el poema puede ser perfectamente también el ámbito de lo sagrado.

Más allá de sus semejanzas, el hermetismo de Lezama es muy distinto del de Góngora. No porque el de éste sea reductible a explicaciones, que no lo es finalmente según Lezama. Sino porque la de Góngora es una poesía que trabaja del lado de la luz--una luz, es cierto, que ciega y aun se devora a sí misma. Góngora--dice Lezama--ha creado el tiempo de los seres o de los objetos en la luz, ha preparado, aun sin proponérselo, el esplendor de la significación, pero sin entregarse al "humilde del sin sentido", sin alcanzar tampoco el "oscuro cuerpo oracular". En otras palabras, su poesía no se interna en la tierra desconocida, no es una afirmación del no nocturno. Apreciación en la que Lezama coincide, aunque quizá por distintas razones, con un poeta de lo luminoso como Jorge Guillén. "Sí, lo gongorino se eleva muy lejos de lo órfico. Se trata de un saber y un entender muy definidos",

Guillén, creo, toca el punto esencial: Góngora no es un poeta órfico. En cambio, Lezama lo es, y en grado extremo. Para él, no hay saber que no sea, al comienzo, un nuevo descenso en el infierno, que no brote de la "fértil oscuridad". Paradiso, sabemos, es la novela de ese descenso; como diría Lezama, la novela de "la ocupación por el hombre de su imagen del destierro, del nombre sin su naturaleza primigenia". En efecto, el destino de su protagonista, José Cemí, es el intento por hacer encarnar una ausencia, la del padre muerto; el intento también por integrar su respiración--de ritmo asmático, atormentado--a la respiración del mundo, al ritmo de la plenitud como sabiduría. Cemí, además, no es tanto el personaje central como el personaje-centro (así como lo había sido igualmente su padre): en él confluyen y se trascienden mutuamente los influjos de sus dos amigos, Fronesis el apolíneo, Foción el dionisíaco. Pero su búsqueda no es sólo impulso de conocimiento; es sobre todo una prueba, una experiencia espiritual. Si no posee de an-

3. Lenguaje y Poesta, 1961. 
temano la luz, Cemí la presiente y de algún modo ya la tiene; su búsqueda, pues, es en gran parte por confrontarse con la sombra, por asimilar lo oscuro. Redimir la luz en la sombra y tio sólo al revés: quizá en ello resida la clave de su destino. De ahí que en el poema que le escribe Fronesis, éste le diga:

Su nombre es también Thelema Semí,

su voluntad puede buscar un cuerpo

en la sombra, la sombra de un árbol

y el árbol que está a la entrada del infierno.

Fue fiel a Orfeo y a Proserpina.

El orfismo para Lezama es la experiencia de la totalidad: una transgresión que nunca se queda en la ruptura sino que incorpora lo desconocido en una nueva y más tensa armonía. "Todo lo que no es demonio es monstruoso"', dice por ello en un poema, cuya paradoja, nos damos cuenta, es sólo aparente. En uno de sus ensayos, Lezama ha distinguido también entre el escritor complejo y el complicado. En el primero se dan "la unanimidad de lo eterno más lo que le llega en el espejo de su enigma' ; el segundo se entrega a lo demoníaco sólo como la ilusión exasperada de su propio poder--se entrega, dice, "a las insinuaciones de la serpiente'". Así,mientras éste resulta parcial en su visión, aquél es necesariamente órfico: quiere identificarse con el esplendor visible y el subterráneo. De igual modo, en uno de sus últimos ensayos, Lezama subraya la diferencia entre la noche de Parménides, que se aisla en el es, un es que no depende de sumergimientos sino que es un continuo, el Uno, y la noche órfica cuyo es se multiplica en la diversidad y sigue el reto de las estaciones, muriendo y renaciendo continuamente con ellas. "Es, está y será", dice Lezama en tono deliberadamente evangélico.

\section{LOS DIOSES DESCENSORES.}

Así, parece evidente que su hermetismo está ligado a una visión órfica del mundo. Como a Mallarmé creo, lo que preocupa a Lezama es el "eterno reverso enigmático" de las cosas. En su libro La Fijeza, hay varios poemas en prosa que tratan este tema, el que, por cierto, se inscribe a su vez en una concepción católica.

Desde el momento--dice en uno de ellos--en que Dios ("el principio") pareció separarse de lo Otro, los hombres se han dividido en dos grupos: "los que creen que la generosidad del Uno engendra el par, y los que creen que lolleva a lo Oscuro, a lo Otro"'. Lezama participa de la segunda creencia. El advenimiento de Cristo--que vino a traer la guerra y no la paz, nos recuerda, como Unamuno--trastrocó fas perspectivas habituales. Con él: "Se ponían claridades oscuras. Hasta entonces la oscuridad había sido pereza diabólica y la claridad (pereza) contenta de las criaturas". La poesía, según Lezama, trastroca igualmente esa falsa simetría de opuestos. Su objeto no es esclarecer un misterio para que éste se vea finalmente reducido, empobrecido, a una verdad clara--como las equivalencias realistas que se buscan en las cifras de la poesía hermética. La poesía es un descifrar y un volver a cifrar. La poesía nace de la resistencia que encuentra el súbito (la imagen) al querer penetrar en lo extensivo (lo real). Pero, advierte Lezama, en el mundo de la poiesis, a diferencia de la física, "la resistencia tiene que proceder por rápidas inundaciones, por pruebas totales que no desean ajustar, limpiar o definir el cristal, sino rodear, romper una brecha por donde caiga el agua tangenciando la rueda giradora', O como lo 
dice en otro poema, de manera más elíptica pero quizá más eficaz y sorprendente: "El dado mientras gira cobra el círculo,/ pero el bandazo es el que le saca la lengua al espejo". En otras palabras, la poesía no es tanto esclarecimiento como revelación: ese instante en que la imagen nos pone ante una totalidad, en que el bandazo rompe con la "embriaguez viciosa del conocimiento". Aun se podría añadir: la revelación, pero del misterio mismo. No hay claridad separada del misterio: revelar es también velar para que lo irrevelable encarne.

"Lo enigmático es también carnal", afirma Lezama en un poema. Es la intuición que lo lleva a escribir uno de sus textos más conmovedores, Rapsodia para el mulo. De una construcción en el fondo muy simple, la intensidad del poema reside en subrayar, hasta la obsesión, hasta la perplejidad, una sola línea (de significación, metafórica, o aun léxica) que, sin embargo, va adquiriendo una densidad abismática. Por una parte, no es posible separar en él lo descriptivo de lo visionario. Con la capacidad que tiene Lezama para potencializar lo real y, esta vez, para hacer de lo entrañable algo estelar, vemos al mulo viajando por el mundo, acarreando y soportando penosa pero mansamente sus cargas; pero vemos sobre todo su destino, su ciega animalidad ("oscuro cuerpo hinchado/por el agua de los orígenes') y cuya única redención es el abismo mismo, cuya única gloria es el avance en "lo oscuro sucesivo y progresivo". Por otra parte, no es posible desligar tampoco este motivo del discurso y el discurso como tal. Aquél, en efecto, no es el tema de la metamorfosis sino el de la resistencia: nunca el martirio quiere ser otra cosa que martirio ("Las sucesivas coronas del desfiladero/-van creciendo corona tras corona"), nunca lo oscuro quiere ser luminoso. Esa resistencia, no obstante, se resuelve en una grandeza: "Su don-dice Lezama-ya no es estéril: su creación/la segura marcha en el abismo". Así también, creo, el.discurso sigue la progresión de la monotonía, de la terquedad rítmica: una sola frase que puede admitir fragmentaciones (pausas) o variaciones (enlaces, recomienzos), pero que casi siempre elude los contrastes. Es una sola frase que ejemplarmente progresa hacia sí misma, que es espejo-abismo-de sí misma: "Con sus ojos sentados y acuosos, / al fin el mulo árboles encaja en todo abismo", dicen los dos últimos versos. Comentando este poema, en uno de sus ensayos Lezama observa: "La resistencia del mulo siembra en el abismo, como la duración poética siembra resurgiendo en lo estelar. Uno, resiste en el cuerpo, otro, resiste en el tiempo, y a ambos se le ve su aleta buscando el complemento desconocido, conocido, desconocido"'. Así, en este poema, Lezama ha estado celebrando a la vez el misterio del mundo y el de la poesía: el misterio que alcanza su esplendor en sí mismo.

Sólo por el secreto, por el otro lado que ellas suponen, viven las cosas y quizá la verdad de ese secreto no esté tanto en lo que encierra como en lo que nos inspira a nosotros. Aun podemos saber que el secreto es una falsía, pero el asumirlo- y el asumirlo como falsíadesencadena ya una necesidad, o una conducta que se vuelve destino. Así, no es el objeto del secreto o su réplica (la verdad), lo que es importante. Lo que es importante es la contrarréplica. Hay un apólogo de Pascal al que Lezama alude y que es, en este sentido, significativo: la historia del náufrago que es recibido como el rey desaparecido y decide obrar como rey aun sabiéndose impostor. Lezama comenta:

La certeza del naufragio es aquí la correspondencia al encuentro del rey falso, 
aceptado violentamente en la necesaria fatalidad de su falsía. He aquí una grandeza que va por encima del ceremonial y del acto de escoger. Devolver en el hombre es intuir el escoger de los dioses. El único indicio que podemos tener de ese escoger de la divinidad, es su correspondencia con el devolver de los humanos. Luego ese devolver es la raiz de lo humano. Devolver con los dones acrecidos es el don de la gracia.

Ese impostor - apenas hay que advertirlo - es el poeta mismo: el dador que conoce la falsía de su dádiva. O el ser que se pone máscaras no tanto para esconder el rostro como para vivir - como lo dice Lezama con frase aún más memorable - "en la visibilidad de la conducta y en el misterio de la extrañeza de las alianzas". Máscara y rostro: otra manera de Lezama de aludir a la relación con lo enigmático y, a un tiempo, de obviar ese tema ya trivial de la "personalidad" del poeta- o de los poetas con "personalidad". La máscara es un conjuro: un modo de vencer la muerte. Pero ese conjuro nace de un impulso a la vez más natural y hondo: nos ponemos máscaras para fluir con el tiempo, no para detenerlo; para oponer a una trasmutación la trasmutaćión misma. En efecto, dice Lezama, la máscara es "el elemento heraclitiano, mientras que el rostro en la lejanía se fija en concepto o en arquetipo". Diversidad y fijeza ("evaporación y centralización", decia Baudelaire): entre estos dos extremos se mueve el yo del poeta. Como lo aclara Lezama: "Si un ser no se transmuta en su máscara no alcanza nunca el misterio de su yo separado y superior". Trasmutarse en su máscara equivale a disolverse en el mundo; un paso más y esa disolución nos depara la imagen de nuestro propio rostro. Dos espirales inversas, como se ve, que encajan una en otra y forman una misma figura circular. El sentido de la máscara corresponde, pues, con el de la metáfora; ambas cumplen dos fases de un mismo movimiento: metamorfosis y reconocimiento, anagnórisis. Es el tema profundo, me parece, de ese poema a un tiempo límpido y casi inasible, Muerte de Narciso, que no por azar está al comienzo de la obra de Lezama.

Digo el tema y quizá debería decir, más bien, el anti-tema. En efecto, Narciso encarna en el mito, como sabemos, la concentración del ser; no el mirar sino el mirarse: su reflejo en el espejo de las aguas es un principio de individuación; aunque es también el principio de un saber absoluto: lo universal contra las contigencias, lo permanente contra la sucesión. En cambio, desde la perspectiva de Lezama, si bien Narciso es el intento por identificarse con lo Uno individual, su búsqueda parece signada por una imposibilidad ( $う$ o un rechazo?): la de abandonarse a la aventura de lo Otro. Asi, contra la voluntad de Narciso, lo que domina en el poema de Lezama es la continua metamorfosis como disolución. Esa disolución empieza por la del significado (o quizá por la de la conciencia misma): en efecto, el poema se desarrolla sin una estructura conceptual muy visible, y no es que sea sólo un incesante flujo de metáforas,sino que éstas, además, casi siempre eluden toda transición referencial. Es el poema que, en verdad, es sólo imagen. En ese flujo metafórico, por cierto, Narciso nunca logra ver su rostro ("Vertical desde el mármol no miraba/la frente que se abría en loto húmedo") o si lo ve lo que contempla son figuras extrañas o aun signos hostiles ("pluma morada, no mojada, pez mirándome, sepulcro"). Narciso no se encuentra a sí mismo sino que es devorado por el espejc de lo vtro ("el granizo/en blando espejo destroza la mirada que lo ciñe"). El poema, entonces, parece la confrontación entre una ausencia o 
una sobreausencia, la de Narciso, y una presencia o una sobrepresencia, la absorbente e imperiosa de todo el univero ("Una flecha destaca, una espalda se ausenta", "Tierra húmeda ascendiendo hasta el rostro, flecha cerrada"). $\mathrm{Y}$, por ello mismo, se ve atravesado por dos ondas rítmicas: la verticalidad de Narciso, que muere siempre ascendiendo ("estirado mármol", "recto sin fin en llamas seco") y la transversalidad de un espacio que, por su parte, se ensancha cada vez más y vuelve más abigarrado en sus relaciones. Me pregunto, además, si este espacio no es ya la primera visión que Lezama nos da del espacio americano: no sólo por su desmesura o exuberancia; también por una suerte de fuerza primigenia con que se hace sentir desde el comienzo del poema ("En chillido sin fin se abría la floresta/al airado redoble en flecha y muerte"'). Aquella doble onda rítmica podria, a su vez, corresponder con la estructura métrica del poema: las primeras estrofas de versos más o menos parejos (el endecasílabo es dominante) van dando paso, progresivamente, a otras cuyos versos tienden ya a lo inconmensurable. "La fundamentación del fuego es la anchura', dirá Lezama en un poemamuy posterior. Narciso, además, muere en fuga, pero no ya en la fuente inicial sino en "pleamar". Esa fuga representa su verdadero drama: el horror ante la diversidad de:lo Otro, lo Otro que dealgún modo es su enemigo("Si atraviesa el espejo hierven las aguas que agitan el oído", "Chorro de abejas increadas muerden la estela, pídenle el costado"). Así, la obsesión de su propio rostro le impide a Narciso reconocerse en ninguna máscara. Es, para decirlo dentro del sistema valorativo de Lezama, un personaje gótico. Pero su fuga ascendente no es una simple evasión; encarna, ciertamente, una fase en el drama de todo poeta; de algún modo es también un signo de las fuerzas germinativas ${ }^{4}$

En un conjunto de poemas que Lezama atribuye a un personaje de Paradiso, titulado por ello mismo Dejos de Licario, se dice: "Narciso mascado por la niebla ascendente,/vuelven los dioses descensores". De suerte que la muerte de Narciso en el inicio mismo de la obra de Lezama parece adquirir un valor propiciatorio y sin duda simbólico: prefigura el advenimiento de la experiencia órfica. Orfeo: el canto ligero y a la vez terrible, uno y muchos rostros, el viaje paradisíaco por lo infernal. La tentación luminosa de lo oscuro, el desencenso en lo Otro. Es decir, todo lo que encarnará luego en la obra de Lezama. De manera significativa, su segundo libro de poemas se titulará Enemigo Rumor (1941). El propio Lezama ha explicado el sentido de ese título: el enemigo rumor es la poesía misma que se constituye en sustancia no sólo real sino también devoradora : 5 Igualmente, podríamos pensar, es el lenguaje de lo Otro, ni oscuro ni luminoso, sino secreto, en cuyo ámbito son simultáneamente posibles la hostilidad y la fascinación. Creo que ya esto es revelador: después de la experiencia de Narciso, Lezama se entrega - se enfrenta - a la experiencia poética como a un reto, o una prueba; también como a un espacio abierto (gnóstico, diría él) cuyos signos son la metamorfosis, la diversidad, la yuxtaposición. Las mil máscaras de un solo rostro.

Quien logre disolverlo todo vencerá al tiempo, parece ser una de las creencias de Lezama 6 . Esa disolución no es simplemente la búsqueda, mucho menos el asedio, de la

4 El poema de Lezama, como se ve, es muy distinto del tratamiento del mito de Narciso tanto en Gide (Le traité du Narcisse, 1891) como en Valéry (Fragments du Narcisse, 1927).

5 Orbita, op. cit.

6 Lezama atribuye esta idea a Roger Bacon; ver su ensayo "Exámenes", en Introducción a los vasos orficos, 1971. 
unidad; es sólo el fluir hacia la unidad. "El río subterráneo es descubierto por el pastor a la sombra del sicomoro", dice Lezama en una breve parábola en que no oculta el humor. Esa coincidencia es, en él, un signo de su visión del arte como una fuerza germinativa y no tan sólo constructiva; es igualmente un signo del placer que encierra toda creación (la risotada del barroco, de que muchas veces habla).

Una de las formas de la unidad, la que nos es dada alcanzar a nosotros, es lo que Lezama denomina lo semejante: no la identidad de las cosas consigo mismas o entre sí, sino la inextricable trama de la heterogeneidad. La verdadera marcha de la metáfora-acota en un poema-es restituir "el ciempiés a la urdimbre"'. Aclaremos que lo semejante es esa urdimbre: una figura que es sólo posible porque cada signo en ella está en función de y en relación con otro signo. Para ilustrarlo con un ejemplo del propio Lezama:

La hoja despierta como oreja, la oreja, amanece como puerta, la puerta se abre al caballo.

Un trotico aleve, de lluvia, va haciendo hablar las yerbas.

En un ensayo, Lezama concluye evocando una leyenda de la India: la del río Puraná, en cuyo caudal impreciso concurren los elementos más dispares, “desemejanzas, chaturas, diamantinas simetrías, coincidentes ternuras"; ese río que carece de análogos y de aproximaciones es, sin embargo, el que conduce a las puertas del Paraíso. No se trata, pues, de un río crisol sino de un hervidero de (con) fusiones; su virtud no está en purificar nada sino en acarrear la multiplicidad del universo. Así también, creo, la unidad en Lezama es una continua expansión; la superposición y el entrecruzamiento, no la reducción. "Todo va hacia el turbión", dice en un poema. Su propia imaginación requiere más las bi-trifurcaciones que lo lineal, y hasta la materia proliferante antes que la configurada. El mismo no deja de reconocerlo: "Mi representación precisa objetos que la burlen;/ los contornos que no desean segunda naturaleza,/ objetos sin equivalencia formales'. Aun propone, sabemos, lo imprevisible como método que conduzca a la unidad: "Lo uno-dice en un poema-tiene que llegarnos como un bulto/ con el cual tropezamos, pues lo uno se acecha/ por exclusión". Excluir lo uno significa acecharlo incluyéndolo todo, para luego ver a lo uno reaparecer en su final esplendor. Lo uno es el imán que hace aparecer toda nuestra diversidad; es también lo que impide que ésta caiga en lo indistinto, o en lo dual. Pero el acto de incluir es, en Lezama, la transgresión de todo límite: ya no la abundancia sino la sobreabundancia. "La abundancia-advierte-es el lleno comunicante, pero la sobreabundancia/ es un sacramento, ya no se sabe de dónde llegó"'; añade igualmente: "sólo la sobreabundancia inunda los rostros y los encarna". Digamos que los "encarna", porque los "inunda", no porque simplemente los esclarezca. La sobreabundancia, en verdad, está ligada en Lezama a la intuición de que al secreto no hay que develarlo sino dejarlo que germine desde sí mismo; recubrirlo con su propio crecimiento y no descubrirlo siguiendo tan sólo una clave. Es por lo que en otro poema de Dador (1960) llega a decir: "El hilo de Ariadna no destrenza el sentido,/ sino la sobreabundancia lanzada a la otra orilla carnal'’. No se trata, pues, de una simple piedra de toque; se trata de una vasta red de magnetismos recíprocos. Es también, creo, la contrarréplica de Lezama a una época crítica que no se lanza a la búsqueda de la Isla Afortunada; equivale, por supuesto, a la desmesura y a la hipérbole como una manera de 
sacudir la duda, no tanto para dar pruebas de la fe sino para hacerla posible, a la vez que es una manera de trasponer los límites de la inteligencia y de volcarnos hacia lo Otro. "Todo lo que no es nosotros tiene que hacerse hiperbólico/para llegar hasta nosotros", dice Lezama. Con lo cual me parece que está definiendo también la naturaleza mítica de su propia obra.

La sobreabundancia puede ser en Lezama una gracia (en el sentido teológico) o un don. No es lo que importa. Importa más saber que él la asume como una manera de existir y que, como la existencia misma, no es ' una posesión sino algo que nos posee', En efecto, hay otros poetas de la (sobre) abundancia. Pensemos, por ejemplo, en uno contemporáneo y también latinoamericano, como Neruda: sus acumulaciones, sus largos inventarios de la naturaleza, sus encadenamientos metafóricos son un modo de poseer el mundo, describiéndolo aun indirectamente; la realidad, en última instancia. sigue siendo más poderosa que la imaginación y se constituye en su apoyo irremplazable. Lezama, en cambio, trabaja tangencialmente, por impregnación. Cada palabra suya-como lo explica en un poema-puede ser un apeiron de arcilla, pero sólo está "sostenida por la respiración nocturna". Y el poeta no hace más que hilarlas como un "Parménides ciego tejiendo la alfombra de Bagdad". Quiero decir: Neruda busca la equivalencia del mundo ("Hablo de cosas que existen, Dios me libre/ de inventar cosas cuando estoy cantando!'); Lezama busca sólo su modulación: su poesía trata, en fin de cuentas, no con la realidad de los seres y las cosas sino con su "respirante diferencia". El mundo, para Lezama sólo puede estar encarnado en la "imagen de la suspensión" que va trenzando el hálito del lenguaje.

Respirar (como) el mundo no es captarlo sino iniciar un acto morfológicamente simultáneo. Es, si se quiere, una analogía de relación, no de contenidos. Ese acto supone, por ello, una distancia que, sin embargo, puede ser más carnal que la presencia misma. Lezama lo sugiere en dos poemas: "la erótica lejanía denomina la mecida extensión de lo estelar", "sentimos en la lejanía de nuestro cuerpo los imanes de un curso remoto". Imantada, erótica, esa distancia "engendra su propio rostro" ; rompe con una causalidad y a un tiempo inicia otra: la de la imaginación del deseo. O, veremos también, la de la memoria. Es esa nueva causalidad (de excepciones morfológicas, diría Licario) lo que permite a Lezama pasar indistintamente de lo estelar a lo entrañable, y viceversa. $O$, aún más; lo que le permite tratar los más refinados artificios de la cultura como si fueran naturaleza pura ("lo sobrenatural naturalizante", dice en un poema), así como desencadenar las fuerzas más elementales como si estuviera combinando esencias alquímicas o cifras de un orden ya establecido. Es justamente en ese punto donde el artificio se vuelve tan necesario como cualquier otra germinación, donde reside lo singular de la escritura de Lezama. Ese punto puede parecer tenso, pero su verdadera tensión está, más bien, en la capacidad para asimilar toda tensión. Para crear la gran conciliación. "Quizá en el otro extremo de la cuerda ocupada por el ángel, no esté la bestia, sino esa feliz coincidencia del otium cum dignitate del humanismo y el pacer de las bestias"'. En ese mismo ensayo, agrega: "El día que podamos establecer un esclarecimiento entre el ocio y el pacer, la verdadera naturaleza será habitada".

No por azar una de las recurrencias en la obra de Lezama es el símbolo de lo que podriamos llamar lo estalactito. La estalactita, recuerda Lezama, es cifra de la eternidad para los taoístas; por ello, al final de Paradiso, Cemí vislumbra la casa de las estalactitas 
antes de llegar a la casa donde velan el cadáver de Oppiano Licario: lo cual parece prefigurar la resurrección de éste. Pero la estalactita sugiere también el refinamiento natural, la cultura que se hace desde la naturaleza misma. Así, en un.poema, Lezama evoca la historia de un muchacho vendedor de estalactitas rasaltamontes: es' sin duda el personaje de una escena costumbrista cubana y el poema alude a una región (Viñales) donde hay grutas; ese muchacho ("doncel' lo llama al comienzo el poeta) es la magia misma que vive en la costumbre y en la pobreza, en la pobreza que lo acostumbra a la magia: el universo para él está finalmente en "su castillo de cuello de cristal" ", es la botella que acaricia antes de dormir y en la que guarda sus cocuyos y las monedas de sus transacciones. El tema del poema no es quizá tanto el cristal como refracción, menos como reflejo, sino como transparencia. "Como la fresa respira hilando su cristal", dice Lezama en el poema de Narciso. Tras el "verismo" de esta imagen se abre otra percepción más penetrante: la materia que, en su proceso mismo de gestación, va simultáneamente cristalizándose. Esa misma percepción la encontramos referida al ser mismo del poema; comparado tácitamente con un gusano de seda, el surco del poema "es su creación:/ un poco de agua grabada". Lo estalactito es, pues, uno de los polos de la obra de Lezama. Lo que él llamaría también la fijeza-título, por lo demás, de uno de sus libros. La fijeza no es la inmovilidad sino el éxtasis en la expansión; esta expansión, por su parte, es dinamismo puro: no movimiento dialéctico, sino expansión del éxtasis mismo. El "reino de las imágenes por el artificio del inmóvil conocido", dice Lezama en un poema. En otras palabras, la fijeza es el universo mismo como absoluto o como Dios: un espejo que no refleja sino que disuelve. Por ello es un espejo que siempre nos burla, como burla a Narciso-como lo devora, más bien. No podemos cristalizar nunca en nosotros mismos, sino en el (oscuro) esplendor de la diversidad. Como tampoco podemos quedarnos con los seres o las cosas sino con su transparencia: la reminiscente imagen en torno a la cual los o las reconstruimos. Es la experiencia de los reagrupamientos temporales que vive José Cemí en uno de los últimos capítulos de Paradiso y que él llama el "ordenamiento de lo invisible", el "sentido de las estalactitas"'.

Nos encontramos también con los símbolos que podriamos denominar, para decirlo con palabras del propio Lezama, de "lo semejante ancestral". Me refiero a la animalia profusa que puebla sus poemas. No se piense, por supuesto, en el registro descriptivo de una fauna tropical. Sin dejar de ser reales, los animales de Lezama son míticos o, más bien, son animales "cifrados". Constituyen para el poeta una "sedosa colección de signos breves", que él resguarda de la mera contingencia. Así, en un poema los presenta en un ámbito ritual, suerte de estrato inmemorial de la imaginación: atraviesan cámaras, saludan a los ujieres y colocan sus cabezas ante "magistrados oscuros, pesados como reyes". Esperan cerca de la corriente-precisa luego Lezama - "la crecida del rio/ que rellena el oído": esperan, en verdad, el flujo verbal que los llevará a su plena existencia. Sería arbitrario, por tanto, reducirlos a meras cifras de un inconsciente atormentado: no traducen ni lo irracional ni lo monstruoso. Son animales órficos, como quizá lo siguen siendo los de cierta mitologia cristiana. Lo que ellos encarnan, en última instancia, es una energía primigenia, la que hará posible el rescate de la naturaleza perdida. Son el instinto puro $\mathrm{n}$, si se quiere, lo oscuro en lo cual intuimos la luminosidad y hasta el orden y la sucesión del instinto. Por eso Lezama los llama "animales de existir fulgurante" y habla 
de sus "sueños irremplazables". Todo principio axiológico, en efecto, está excluido de su visión: tan finos son los antílopes como las "serpientes breves, de pasos evaporados". Como un nuevo Orfeo, Lezama establece un secreto entendimiento con todos ellos. En un poema irónicamente franciscano, evoca su trato con los animalejos más inferiores (¿o más repelentes?); entre ellos, la araña. El trato resulta ser revelador, le descubre:

que la araña no es un animal de Lautréamont,

sino del Espíritu Santo; que tiene apetito de hablar

con el hombre; que tiene convencimiento de que la amistad

del hombre con el perro y el caballo ha sido inútil

y holandesamente contratada. Si se le dejara subir por las piernas

no en los bordes de la pesadilla sino en el ancla matinal,

llegaría a los labios, comenzando su lenta habladuría secular.

Pero quizá lo central del poema esté en esta otra visión: "El ámbito de la araña-añade Lezama-es más profundo que el del hombre,/ pues su espacio es un nacimiento derivado, pues hacer/ del ámbito una criatura transparenta lo inorgánico"'. Apenas hay que advertir que, con esta última estrofa, Lezama nos está dando tácitamente una visión del poema mismo, como tal. Como el ámbito de la araña, el ámbito del poema es un hilado de relaciones; una actividad que construye, no un objeto construido; no un cuerpo a la vista, sino la mirada que lo hace posible. De igual modo, se revela, así, uno de los rasgos esenciales de esta obra poética: el poema como campo de un desarrollo verbal y a la vez como reflexión sobre el poema mismo. Con lo cual me parece que Lezama quiere poner el acento en esto: el poema no es un equivalente del mundo, sino que el mundo debe estar regido por un sistema poético, por el principio relacionable, por el logos dè la imaginación.

\section{LA JUSTICIA METAFORICA,}

De ahí que el mundo en la poesía de Lezama no sea tanto un discurrir como un discourso. "En una misma agua discursiva/ se bañan el inmóvil paisaje y los animales más finos", dice Lezama en un poema; en otro, habla del "discurso del fuego acariciado". Con lo cual tiende a sugerir que no sólo vemos el mundo a través del lenguaje sino que, además, lo vemos como lenguaje. Un lenguaje, creo, que en Lezama es sobre todo el de la memoria. $\mathrm{O}$, mejor, que es el lenguaje como memoria.

No sólo la memoria es ausencia de contenidos y presencia de relaciones; también cumple la doble operación de acumular y, a la vez, de decantar. "'Llenando un cántaro al revés, vaciando, vaciando", se presenta Lezama en un poema. Dentro de esta misma línea, la naturaleza de la memoria parece análoga a lo que Lezama llama el ocio: un reposo que parejamente es actividad, una desposesión que es también una posesión, y hasta una metamorfosis que no puede funcionar sino como final reconocimiento, como anagnórisis. En uno de sus últimos poemas, Lezama define al ocio con esta visión que es, en í misma, la del esplandor de la fijeza:

El ocio tiene el pez invisible, pero saltante en las

redes de la planicie,

no es un paseo entre las máscaras y las jarras, sino 
el alborozo de los rostros en la proliferación de

la música.

La memoria, ciertamente, para Lezama, no es una simple posesión sino la única posesión. Sólo poseemos-y conocemos, según Platón, advierte Lezama-lo que recordamos. La memoria, en este sentido, es la resistencia contra el flujo del tiempo. Su función, por tanto, es equivalente a la de la imagen en el poema: la imagen, según Lezama, es también la resistencia final en que toman cuerpo las sucesivas metáforas. Pero no sólo recordamos lo que personalmente hemos vivido o conocido; tampoco el recuerdo es el resultado de una lucidez en la experiencia. El recuerdo, en Lezama, está ligado igualmente a una experiencia oscura, ni siquiera vislumbrada como tal; digamos, está ligado al subconsciente. En efecto, pocas poesías, como la de Lezama, suscitan la impresión de ser el desarrollo de un subconsciente casi al estado puro, que maneja su propio lenguaje de cifras en el nivel irreductible de los signos. De ahí que sea una poesía no sólo hermética, sino también visionaria. O más bien, que sea hermética porque, ante todo, es visionaria.

Pero, además, la memoria en Lezama se identifica con un inconsciente colectivo y así adquiere su verdadera dimensión: la amplificación de la hipérbole. "Hyperbole de ma mémoire'", podría decir Lezama con Mallarmé, y ciertamente lo dice en algún pasaje de su obra. En esa hipérbole, lo personal colinda con lo ancestral y lo mítico, la memoria ya no es entonces resistencia contra el flujo del tiempo, sino más bien afloración del tiempo y aun quizá presencia del tiempo mismo. "Memorizamos desde la raíz de la especie", afirma Lezama en un ensayo, y luego reitera lo mismo en un poema: "mi memoria precisa las danzas de mi nacimiento". Aparte de que el regreso a la raíz o al nacimiento de algo no propone ninguna involución sino el vislumbre de lo primordial, el reencuentro con un tiempo que es ya todo el tiempo, lo que Lezama busca con la hipérbole memoriosa es penetrar en un srecimiento, en una germinación: insertar las cosas en su verdadera (conocida, desconocida) naturaleza relacionable. Así, en un poema de ambiente habanero (o de mitología habanera, como ya hablamos de mitología bonarense en Borges) como $\mathrm{El}$ cocbe musical, un músico popular no sólo se ve transfigurado en una criatura casi órfica y aun pitagórica; también la fiesta nocturna que él concita se ve finalmente regida por la presencia de lo subterráneo: "Bailar es encontrar la unidad que forman los vivientes y los muertos./ El que más danza, juega el ajedrez con el rubio Radamanto'. Hay, de igual modo, una figura recurrente en la obra de Lezama (aparece en el capitulo XII de Paradiso y en el último poema de Dador): el dibujo de una jarra (la jarra es en Lezama una cifra de iniciación), cuyas escenas al ser descritas se ven amplificadas, inesperadamente, a una dimensión no ya real sino cósmica y aun mítica. Esta figura revela el arte de Lezama: por una parte, su capacidad para insertar lo mensurable en lo inconmensurable; por la otra, su poder de organizar el universo según las escalas (próximas, remotas) de la memoria.

Pero ni como resistencia frente al tiempo ni como su afloración, la memoria en Lezama no es simplemente un resto, lo que queda de algo. Es, por el contrario, una continua creación; es, en sí misma, una dimensión metafórica. Incluso, quizá no sea arbitrario decir que el prodigio metafórico de Lezama se deriva de la memoria. Como ésta, su metáfora, en verdad, es más penetración en lo invisible que en lo visible; en ambas también la urdimbre devora al objeto, lo mítico se sobrepone a lo real. Pero sobre todo la metáfora es posible en Lezama porque la precede la memoria de la diversidad y de la 
sobreabundancia, una suerte de vasta lectura del mundo. Así, es la memoria la que conduce, en última instancia, a lo que él llama la justicia metafórica. En el poema Recuerdo de lo Semejante, Lezama dice:

El sobreabundante tiene la justicia metafórica, como el monarca hereda y engendra el bastardo, se disfraza y saborea el regicidio, confundido con el parodista de Bizancio.

¿No regresamos de algún modo, en este poema, al apólogo ya citado al comienzo de Pascal? En todo caso, es significativo que la justicia de que se habla en él esté rodeada por lo que aparentemente la contraría y aun la niega: vale decir, por la bastardía, el disfraz y la parodia. Pero no olvidemos que esa justicia es metafórica, lo que significa que es impartida por la metáfora. Y la metáfora en Lezama, sabemos, supone lo Otro, Lo semejante que no es sino la trama de lo heterogéneo. La metáfora es lo justo en lo diverso y aun en lo contrario; no se trata de le mot just, que precisa y define, sino de la justicia de la sobreabundancia, de la (con)fusión entre todos los elementos opuestos. Esa justicia, por tanto, consiste en metamorfosearse con todos los personajes del drama sin condenar a ninguno; de algún modo quiere prefigurar, así, una nueva (la verdadera) justicia cósmica. Con razón ha podido decir Lezamaque al escritor sólo se le puede pedir cuenta de la fidelidad o no a una imagen; de ello depende también su destino. Sólo por la fidelidad a una (su) imagen, piensa Lezama, el hombre puede habitar el destierro (vale decir, la vida misma) vislumbrando el Paraíso, y sentir esa dicha-de la que habla en uno de sus últimos ensayos-del efímero que puede "contemplar el movimiento como imagen de la eternidad". En verdad, es la justicia metaforica la que prepara para el júbilo ( la fijeza) del esplendor final que, no por paradoja, se ha purificado en lo oscuro y ha encontrado en él su secreto.

En un poema de Enemigo Rumor, después de confrontar la noche y el destierro, Lezama concluye invocando, justamente, la imagen del esplendor. Dice en ese poema:

La mar violeta añora el nacimiento de los dioses, ya que nacer es aquí una fiesta innombrable, un redoble de cortejos y tritones reinando.

...

Dance la luz reconciliando

al hombre con sus dioses desdeñosos.

Ambos sonrientes, diciendo

los vencimientos de la muerte universal

y la calidad tranquila de la luz.

Ese esplendor, lo vemos, es una añoranza, una nostalgia. Es, por ello mismo, una memoria y, como tal, rige toda la aventura de la obra de Lezama en su penetración de lo oscuro. Pero precisemos: no es simplemente la memoria de un pasado, sino de un futuro, es decir, de un nacimiento. Recordemos esta frase de Lezama: "todo está dispuesto para un nacimiento, no para una repetición', Por otra parte, ese esplendor parece aludir también al espacio americano, incluso al espacio insular de Cuba; sólo que a la connotación geográfica de lo insular se superpone en Lezama otra que es de carácter mítico: lo insular es la imagen de la Isla Afortunada, sobre la cual tánto se debate en Paradiso, o "la imágen renacentista de la Isla Americana', como ha señalado Cintio Vitier 7 . Por ello, ya no se

7 Lo Cubaro ox la Poesta, 1958. 
trata del espacio devorador del poema a Narciso, sino del espacio abierto de la gran reconciliación. El espacio donde sería posible encontrar el logos de la imaginación, o, como lo ha indicado igualmente.Lezama, donde se estableceria la identidad entre el mundo de la gnosis y el de la physis.

University of Pittsburgh, 1973

GUILLERMO SUCRE 